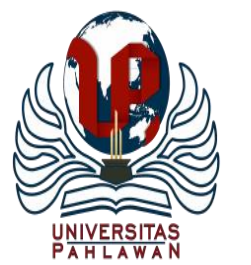

Edukatif : Jurnal Ilmu Pendidikan Volume 3 Nomor 5 Tahun 2021 Halm 3026 - 3034

EDUKATIF: JURNAL ILMU PENDIDIKAN

Research \& Learning in Education

https://edukatif.org/index.php/edukatif/index

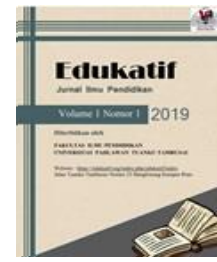

\title{
The Students' Senior High School Experiences in Poetry Reading Activities Assisted Vocabulary Learning: Narrative Inquiry
}

\author{
Siti Rohmah $^{1 凶}$, Muhammad Reza Pahlevi², Abdul Kodir Al-Baekani ${ }^{3}$ \\ Universitas Singaperbangsa Karawang, Indonesia ${ }^{1,2,3}$ \\ E-mail : 1710631060003@ student.unsika.ac.id ${ }^{1}$, mreza.pahlevi@ fkip.unsika.ac.id $^{2}$, \\ akodir.albaekani@staff.unsika.ac.id ${ }^{3}$
}

\begin{abstract}
Abstrak
Pengajaran dan pembelajaran kosakata melalui puisi sebagai bagian dari sastra tidak menekankan dan tidak berfokus kepada siswa sebagai bagian penting dari pembelajaran bahasa. Terdapat tiga temuan penelitian ini untuk mengetahui bagaimana pengalaman siswa dalam belajar kosakata melalui kegiatan membaca puisi. (1) Siswa mengeksplorasi puisi dalam hal kosa kata dengan antusias. (2) Puisi sebagai media yang ramah digunakan dalam pembelajaran kosakata. (3) Puisi menyajikan pengalaman belajar yang menyenangkan sekaligus menantang bagi siswa untuk belajar lebih banyak. Naratif Inkuiri menunjukkan tentang cerita dan pengalaman siswa dalam belajar melalui otobiografi, dokumen kehidupan, kisah hidup, dan sejarah. Pengumpulan data dilakukan melalui kuesioner dan wawancara. Wawancara menggunakan wawancara semi terstruktur dengan empat siswa kelas dua di SMAN 1 Cikarang Selatan sebagai partisipan untuk memberikan pengalaman mereka dalam belajar dengan kegiatan membaca puisi dalam pembelajaran kosakata. Untuk memperkuat data wawancara, digunakan item angket yang mencakup sepuluh poin yang menunjukkan tentang bagaimana pengalaman siswa dalam pembelajaran kosakata berbantuan puisi melalui kegiatan membaca puisi. Kuesioner dikumpulkan dari 46 siswa yang menyukai pelajaran puisi dan bahasa Inggris di sekolah yang sama.
\end{abstract}

Kata Kunci: membaca puisi, pembelajaran kosa kata, pengalaman siswa.

\section{Abstract}

Teaching and learning vocabulary through poetry as a part of literature is not emphasized and focused to the students as an important part of language learning. To fill the gap, there are three findings of this study to find out how the students experiences in learning vocabulary through reading poetry activities. (1) The students lead to explore poetry in term of vocabulary enthusiastically. (2) Poetry as friendly use media in learning vocabulary. (3) The poetry serves a joyful learning experience while it challenges students to learn more. Narrative inquiry shows about the students' story and experiences in learning through autobiographies, document of life, life stories, and histories. The data were collected through questionnaire and interview. The interview used semi structured interview with four students in second grade at SMAN 1 Cikarang Selatan as participants to give their experiences in learning by reading poetry activities in vocabulary leaning. To strengthen the interview data, there was used items of questionnaire included ten points that shown about how the students experiences in poetry assisted vocabulary learning through reading poetry activities. The questionnaire gathered from 46 students that like poetry and English lesson in the same school above.

Keywords: Poetry reading, vocabulary learning, student experiences.

Copyright (c) 2021 Siti Rohmah, Muhammad Reza Pahlevi, Abdul Kodir Al-Baekani

$\triangle$ Corresponding author

Email : $1710631060003 @$ student.unsika.ac.id

DOI : https://doi.org/10.31004/edukatif.v3i5.1017

ISSN 2656-8063 (Media Cetak)

ISSN 2656-8071 (Media Online) 
3027 The Students' Senior High School Experiences in Poetry Reading Activities Assisted Vocabulary Learning: Narrative Inquiry - Siti Rohmah, Muhammad Reza Pahlevi,, Abdul Kodir Al-Baekani

DOI: https://doi.org/10.31004/edukatif.v3i5.1017

\section{INTRODUCTION}

In the classroom, teaching and learning vocabulary is not emphasized or focused to the students as an important part of language learning. It is reported by Alabi (2015), the most common idea in teaching is crucial importance vocabulary of vocabulary in communication and in language teaching. Now-days teaching learning vocabulary as considered as important instructional aims for teachers in all content area in the middle grade school. As an important most part, vocabulary learning occurs in school is not just a school-based phenomenon because many children begin formal school "with rich vocabularies but not formal vocabulary instruction"(Brabham, E G; Villaume, 2002). In vocabulary learning, producing and expressing of word is important ability for student, it means understanding a word meaning making as a reflection and awareness in vocabulary learning(Rosenhan \& Galloway, 2019).

Learning vocabulary need the media to explaining and gaining the new vocabularies. Blachowicz \& Fisher $(2004$, p. 69) get the result that effective vocabulary instruction can make a difference. Important research-based practices include encouraging students to play with and explore words, actively teaching students new vocabulary, helping students build strategies to learn new words independently, reading to students, and encouraging students to read widely. By incorporating these practices in the curriculum and instruction, it can instill in the students an appreciation for words and motivate students to build their vocabularies, not only for their school assignments, but for the rest of their lives (Aydinoğlu, 2013). Reading of literary text in the classroom accelerate the emotional intelligence, when the literature text use in the classroom. It exposes student to critical thinking (Hanaeur, 1997, p. 21) consider the indiscernibility of literary study and usage in language teaching. One of some ways to teach and learn vocabulary is literary text such as poetry. Poetry will be use great extend to analyze and demystify language learning, poetry is therefore thinking aloud to understanding level of Interpreting life with exploring the idea.

Poetry includes in literature context mostly familiar in language learning context to express what people say and mean. According to Denman (1988), poetry is the most neglected component in language curriculums, that some are "turned off all forms of poetry, thinking that all poetry has to be heavy with some sort of deep, hidden meaning that they, for the life of them, cannot see" (Aydinoğlu, 2013). Through poetry, the students explore more creativity in their self with some "hidden meaning" or the real vocabulary relates with the feeling and the mindful (Cui et al., 2015). Poetry will be use great extend to analyze and demystify language learning, poetry is therefore thinking aloud to understanding level of Interpreting life with exploring the idea (Alabi, 2015). Poetry also is a part creative written art that increasing being used in educational context (Macdonald, 2018). Poetry is one of the oldest genres in literary history. The majority of these definition are limited to characteristics such as verse, Rhyme, and meter, which are traditionally regarded as the classical elements that distinguish poetry from prose. Explanations of the genre which combine poetic language with linguistics elements other than rhyme and meter do more justice to non-traditional forms such as free verse or prose poems (Saefullah, 2019).

In teaching vocabulary through poetry, vocabulary is the important aspect in English. Vocabulary recognizes of the most essentials parts of language profiency (Albaladejo, Coyle, \& de Larious, 2017). Vocabulary is the total number of words that are needed to communicate ideas and express what the speakers' meaning (Alqahtani, 2015). It is why vocabulary use in teaching English Classroom. Some technique and media to teaching vocabulary will be prepare to the teacher that accordingly with the student need it to students' practicing. This study will find show of using poetry-based vocabulary teaching activities on vocabulary learning. As Duff and Maley (2002: p, 78) state, literary texts such as poetry offer wide range of interesting and practical language development materials for both teachers and student at different age and levels. Analysis of the poetry stated that the task encouraged both of student creativity and self-awareness and offered opportunities for English discourse. This is focus on poetry as a creative product, through written 
3028 The Students' Senior High School Experiences in Poetry Reading Activities Assisted Vocabulary Learning: Narrative Inquiry - Siti Rohmah, Muhammad Reza Pahlevi,, Abdul Kodir Al-Baekani

DOI: https://doi.org/10.31004/edukatif.v3i5.1017

poetry by the student first, to gain the ability of students' vocabularies, then continues the researcher used small specific vocabularies in English and not generalized (Rosenshan \& Galloway, 2019). The reading and rereading of poetry through read-aloud and choral reading activities promotes fluency. Beginner readers more easily understand the meaning of poetry because it shows brief but powerful set of literature context (Chaton, 1993).

To make poetry as a meaning making in learning, there are some stages below accordance result from Hess (2003, pp. 22-24), first step is building on new literacy studies that drawing upon their own experiences as urban high school teachers. They may also guide students' own individual reading of poems from the printed reader and assist them for homework. In addition, the student gives their schemata as a unit of knowledge or a pocket. The student understands about everything word in the world to write and brainstorming poetry. Vocabulary preview is to connected the next step what important to the student because words which present difficulty but are essential for the uncovering of the essential meaning of the poetry. then doing Bridge that is a sentence or two connects the trigger activity to the text to be read. Also, return to the poem and analyze its language as it pertains and adds to the meaning of the poem. They locate the verbs and say which one contributes most meaning to the poem. The next part, student stand up and mingle as they share their chosen meaning with classmates and explain what they have made the choice. Such as a conclusion frequently leads us to a discussion of what is needed for happiness (Hess, 2003).

However, students' experiences or practice on poetry assisted vocabulary learning is very important. The effect of poetry-based instruction on the student toward foreign language learning was effective to increase communicative abilities and vocabulary learning (Özen \& Behbood Mohammadzadeh, n.d.). Practicing vocabulary in the classroom showed by some literary works, it concerns from using literature in the classroom provided additional of grammar practice, vocabulary learning, and translation (Khatib \& Rahimi, 2012). The activity respect through the types of question asked the teacher, elaboration the learner response and teacher facilitation of difficulty of classroom discussion. The importance of using literature in classroom, such as poetry express activity for the learners. Malley \& Duff (1991, p. 49) points out the reasons for the suitability of literature as resource in EFL and ESL setting, there are including universality as all known languages have literature, non-triviality as an unlike many of other language teaching resources texts or experience, personal relevance about ideas, events and things expressed in literature, variety about a great variety of language and subject matters talked about in literature, interest literature is by nature intrinsically appealing as it deals with familiar subject matters in an attractive and interesting (Jocson, 2006).

Utilizing poetry in learning has been widely explored by many researchers. They tend the effectiveness and implemented of poetry in learning English. Their findings showed the student can enjoy and motivate with poetry-based vocabulary teaching activities on the learner on the learner vocab (Alabi, 2015; Arvieta, 2019; Ozen, Teaching Vocabulary Though Poetry in EFL Classroom, 2012). Based on mentioned of previous study, it is clear that there is methodological gap from previous study. The study emphasizes students' experiences in poetry assisted in learning vocabulary. It is clearly how poetry exploring and reviewing the efficacy to learn the vocabulary, therefore this present study concern in students' experiences in poetryassisted vocabulary learning.

\section{METHOD}

The study focuses on collecting primary textual data and it using interpretative analysis student behaviour and statement will be carefully in this study that relies on rich student data from relatively small sample, in order to allow for good depth of analysis. Narrative inquiry shows about the students' story and experiences in learning through autobiographies, document of life, life stories, and histories (Murray, 2009). It is suitable with focused of the study. In addition, this study used qualitative research to give profound analysis 
3029 The Students' Senior High School Experiences in Poetry Reading Activities Assisted Vocabulary Learning: Narrative Inquiry - Siti Rohmah, Muhammad Reza Pahlevi,, Abdul Kodir Al-Baekani

DOI: https://doi.org/10.31004/edukatif.v3i5.1017

as a data result. Qualitative research design gathered the data through observation, interviews, open-response questionnaire and diaries. It means research design relate with the study aims to know deeper about students' experiences in poetry assisted in vocabulary learning.

To obtain the data, the researcher provides the procedure. There are not following the formula for doing history research, but rather to explain the step in the particular study below (Murray, 2009) Develop the research design: including question to ask participant about their language learning story; (a)what they will study? (b)why they will study it? And (c)how they will study it?. Then, prepare interview question: these questions pertaining to why it was important for the learners to learn the language, how they went about it, what resources they use it, what resources they used. And how successful they were in achieving their goal. Also, select the participants and explaining to the participant about the research and engage the participant to join with research. The role of in interpretation process, also the privacy of the data. Last one is conduct and transcribe the data.

The data were collected through questionnaire and interview. The interview used semi structured interview with four students in second grade at SMAN 1 Cikarang Selatan as participants to give their experiences in learning by reading poetry activities in vocabulary leaning, it means the student like the diction and poetic arts. The list of ten questions to the participants is adopted from (Puji Widodo et al., 2016). The interview spent 30-50 minutes and it will conduct with relax also warm interview. In every interview part, the participants share about the experiences in poetry-assisted in vocabulary learning. To interpret and analyze the data collection, the researcher uses categorical content analysis and the constant comparative method to gain the result and discussion (Murray, 2009). To strengthen the interview data, there was used items of questionnaire included ten points that shown about how the students experiences in poetry assisted vocabulary learning through reading poetry activities. The questionnaire gathered from 46 students that like poetry and English lesson in the same school above. Questionnaire is adopted from a study done by Ouliaris, C. (2019) Each number stand for the following responses that recorded by google forms: (1) strongly disagree, (2) disagree, (3) uncertain, (4) agree, and (5) strongly agree. The graphic was presented the result of this research (Sholikhah, 1970).

\section{RESULT AND DISCUSSION}

The result was obtained through interview. questionnaire, and documentation. There are some general pattern findings of this study. (1) The students lead to explore poetry in term of vocabulary enthusiastically. (2) Poetry as friendly use media in learning vocabulary. (3) The poetry serves a joyful learning experience while it challenges students to learn more.

\section{The students lead to explore poetry in term of vocabulary enthusiastically}

Poetry has some features that mediate students to learn vocabulary differently. It has an interesting word and meaning. It is also simple and easy to learn wherever. It encourages students to learn vocabulary enthusiastically. The students are encouraged to learn deeper in vocabulary through poetry. The explanation from the students will be find out as students' Vignette 1, 2, 3, and 4.

Student's Vignette 1

I like learning with poetry, sometimes poetry related with story of our life. Poetry makes me to explore about words and meaning of words.

Student's Vignette 2

I think, poetry as a easily and simple text that explain about the diction. In every sentence of poetry, it have meaningfully of words and make me to find the understanding of that.

Student's Vignette 3. 
3030 The Students' Senior High School Experiences in Poetry Reading Activities Assisted Vocabulary Learning: Narrative Inquiry - Siti Rohmah, Muhammad Reza Pahlevi,, Abdul Kodir Al-Baekani

DOI: https://doi.org/10.31004/edukatif.v3i5.1017

Based on my experiences, poetry is effectively to use in learning vocabulary. It makes English easily to learn though sometimes I forget about the words in English but if I hear the words, I understand meaning of the words.

Student's Vignette 4

My experiences in using poetry to learn of words is exciting. Because poetry have some kinds of words, so make me feel learn more

Based on mentioned interview transcription, it is clearly stated that poetry attracts students to learn vocabulary interestingly and enthusiastically. It also builds students awareness to learn vocabulary well. Vocabulary in poetry given experiences to the student about a deeply meaning to explore the real meaning of the words. It creates the students actively to know deeply about what the poetry tell is and to know what the meaning of words in poetry. Several types of poetry explored about life and related with to real life, it makes the student learning with enthusiast with poetry. The students also find the simple sentences that shown the words, so that is easily digested by students. Some kinds of words provided by poetry such as the tenses, pronoun, adjectives, and word classes that shown on evidence transcription:

\section{Student's Vignette 5}

Finally, there were a few words, and it looked like helped, it seemed like it was "help", but in the end, it was "Ed", tenses I mean. Last, I learned was pronouns, for example there is the word He, it turns out that if it is put behind it, it becomes him.

Student's Vignette 6

I almost found about adjective as "rich, rise, fall"

Student's Vignette 7

There are a lot of synonyms, just like in Indonesian, they say the same thing, only the words in English are different, for example "maybe and probably".

Some of the students express about kinds of words, included the tenses, adjective, and synonym of words. It is also strengthened by questionnaire result on how illustrated that almost students agreed that poetry mediates them to learn vocabulary easily and interestingly. Questionnaire transcription result is presented as follow:

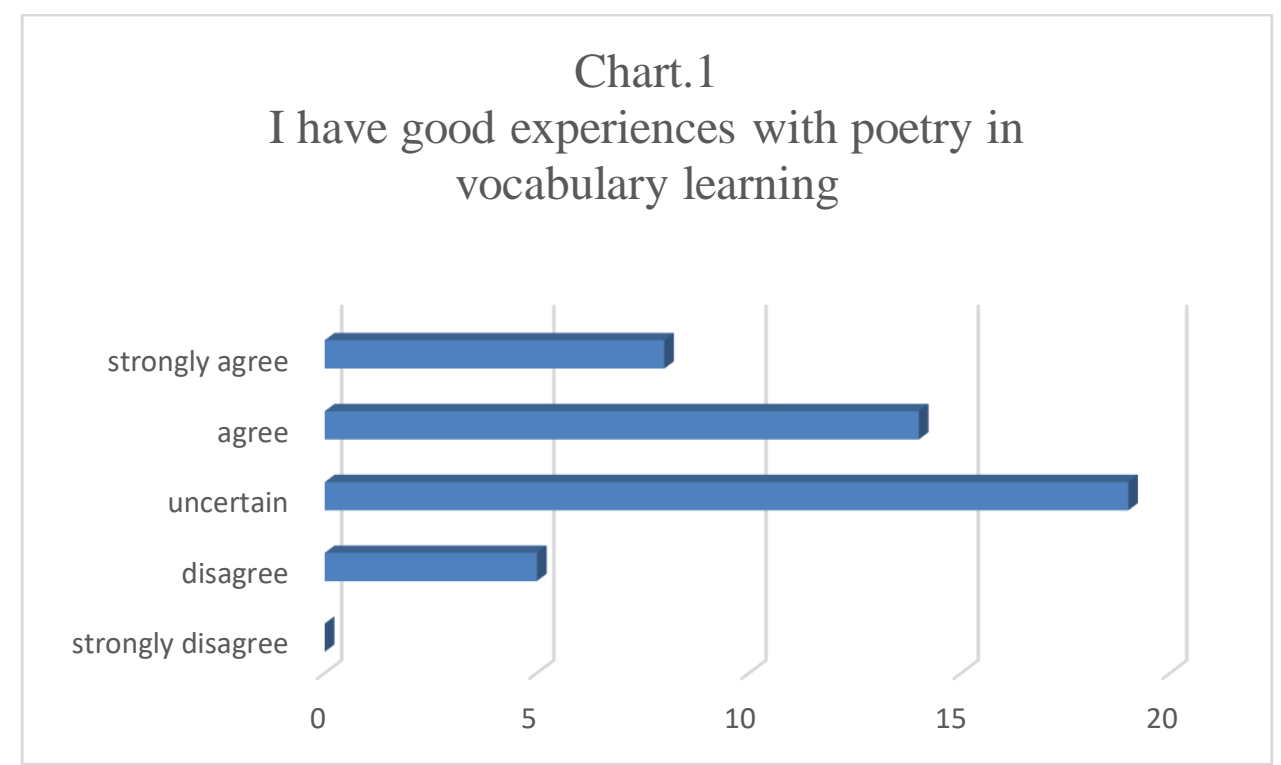

From the statement in the questionnaire, it is clearly stated that almost students perceived that is uncertain on having good experiences in poetry assisted vocabulary learning. However, students who agreed 
3031 The Students' Senior High School Experiences in Poetry Reading Activities Assisted Vocabulary Learning: Narrative Inquiry - Siti Rohmah, Muhammad Reza Pahlevi,, Abdul Kodir Al-Baekani

DOI: https://doi.org/10.31004/edukatif.v3i5.1017

that poetry as good experiences in vocabulary learning had greeter amount than disagree statement. It showed that the students had good experiences in learning vocabulary through poetry. This data used to strengthen how poetry serve students in learning vocabulary, indeed four students that declared poetry is not proper still adapted to use poetry in learning vocabulary.

\section{Poetry as friendly use media in learning vocabulary}

In vocabulary learning, the student needs the media that provide some kinds of words. Poetry mediates the student to learn easily that show simple text and easily to find the text, not only in a book but also in the social media account where the student was find poetry as a media in learning. It can line with the interview transcription:

\section{Student's Vignette 8}

Poetry is easily to find in a book or social media account of poetry, also as a shorter text than other English text that I read before.

Student's Vignette 9

I find poetry in some platform in some media with different style author to write poetry. It ways make me deeply give a meaning of some words that make me curios to konow about the words.

The interview transcription shows the student chosen poetry as a media in vocabulary learning. Poetry facilitated the student in learning and expressing situation in some words. It was also proven through the following questionnaire data:

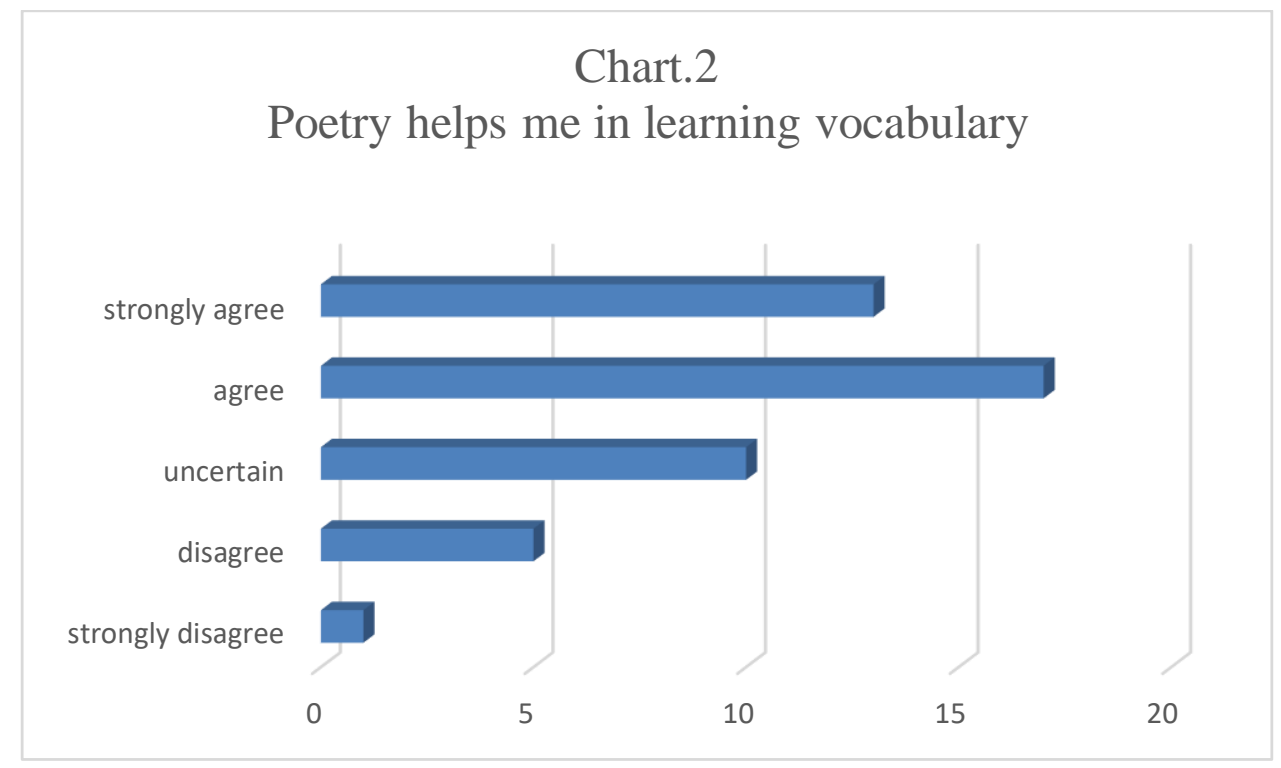

The chart described about the usefulness of poetry in help student to learning vocabulary. Based on mentioned bar chart it illustrates that almost students agreed that poetry assisted and only a few students who strongly disagree. It means the use of poetry in vocabulary learning assist students to learn interactively since poetry serve students some features that are used in learning vocabulary. In addition, poetry give rules to mediate the students in learning vocabulary. It definite with the interview record:

Student's Vignette 10:

Firstly. I find a text of poetry from a book, then underline of the unknown meaning of some words of the text. Certainly, I give some prediction of the meaning of words before I ask my friend about it or found the meaning in the dictionary. Last, rewrite the poetry and the story of poetry's about. 
3032 The Students' Senior High School Experiences in Poetry Reading Activities Assisted Vocabulary Learning: Narrative Inquiry - Siti Rohmah, Muhammad Reza Pahlevi,, Abdul Kodir Al-Baekani

DOI: https://doi.org/10.31004/edukatif.v3i5.1017

Most of the student using poetry to search words they did not know before. To begin with, they read poetry and give an opinion about the poem. In addition, they wrote the words with prediction meaning without using dictionary to translate. Furthermore, students connected the meaning of every sentence of the poetry. Then, they used dictionary to fix the meaning of the poetry. In conclusion, the poetry was translated with appropriate meaning.

\section{The poetry serves a joyful learning experience while it challenges students to learn more.}

Poetry gives students experiences with some challenges of the text. The students gained new vocabularies with explored more about what the words meaning. It is clearly appropriated with the interview transcription:

Student's Vignette 11

I enjoyed leaning with poetry even I feel it some challeges to explore the sense of poetry

\section{Student's Vignette 12}

Poetry makes me feel comfortable to learn with it. It means poetry have thousand meaning of words

Refers to interview transcription, it is generally accepted that the poetry provides meaningful learning and challenges students to learn more values. Students used poetry in learning vocabulary though it is more difficult than other text. Besides that, poetry make the students enjoyed with simply sentences that mostly students find before. It is also reinforced with questionnaire:

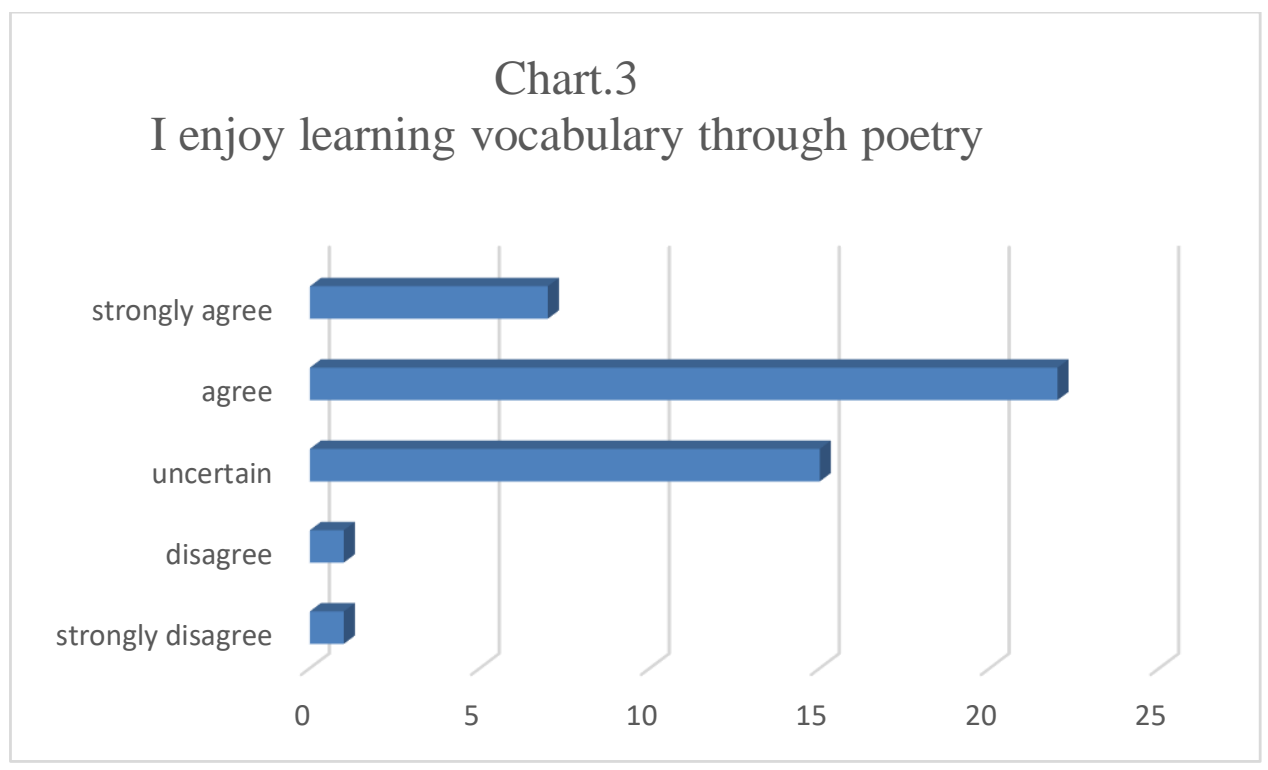

The data in questionnaire have 46 participants from senior high school in eleven grades. It showed that most of the respondents enjoyed learning vocabulary with poetry assisted with 22 people fill with the agree items. The evidence that poetry make the students enjoy in learning vocabulary.

\section{Discussion}

\section{The students lead to explore poetry in term of vocabulary enthusiastically}

The students are encouraged to learn deeper in vocabulary through poetry. Poetry creates an interesting media that stimulates students to learn vocabulary. It also assists students to have awareness to obtain new vocabulary. It is same with Karen Simecek \& Viv Elllis (2016) that poetry have value as part of improving literacy skill and language development that serve the goals of relationship between meaning making and selfconscious organizational pattering of language. The student explored good experiences while their learning vocabulary with poetry. The experiences make the students to know more about what the poetry explain and 
3033 The Students' Senior High School Experiences in Poetry Reading Activities Assisted Vocabulary Learning: Narrative Inquiry - Siti Rohmah, Muhammad Reza Pahlevi,, Abdul Kodir Al-Baekani

DOI: https://doi.org/10.31004/edukatif.v3i5.1017

the keyword of the poetry where can describe meaning of text. It presented based on vocabulary items by poetry to collecting vocabulary with different ways to make students learning actively (Ozen , Teaching Vocabulary Though Poetry in EFL Classroom, 2012).

Poetry connected with the real-life story that makes student understand able about theme of poetry. It is appropriate with David Ian Hanaeur (Hanaeur, 1997) explains that poetry facilitates L2 knowledge and reading poetry presents an eminently suitable task in relation to this issue, for here, meaning construction, focus on form naturally linked. Through exploring one by one words of poetry that have term vocabulary, poetry provides the simplify sentence in the text. Poetry express words and actions provide information about their thinking as well as the belief of the significance of reading strategies in teaching and comprehending literature (Ebrahimi \& Zainal, 2018).

The students also find the simple sentences that shown the words, so that is easily digested by students. Some kinds of words provided by poetry, about the tenses, pronoun, adjectives, and word classes. It can conclude by (Healy \& Smyth, 2017) that poetry brings the classes of word which distinguish between verbs, adjectives and learn about new tone.

\section{Poetry as friendly use media in learning vocabulary}

Using poetry to learn vocabulary was mediated the student to learn easily that show simple text and easily to find the text. Students find it helpful when learning vocabulary through poetry. It strengthens with (Ebrahimi \& Zainal, 2018) claims from all the literary genres, poetry is the one therefore a very versatile and highly usefull too in the vocabulary learning classroom.

As a friendly media in learning vocabulary, there are some stages who student explored based on the experiences in poetry assissted vocabulary leaning. To begin with, they read poetry and give an opinion about the poem. In addition, they wrote the words with prediction meaning without using dictionary to translate. Furthermore, students connected the meaning of every sentence of the poetry. Then, they used dictionary to fix the meaning of the poetry. In conclusion, the poetry was translated with appropriate meaning. Mostly of the step was widely from Hess (2003) includes (a)building knowledge of the students, (b)trigger or schemata about the poetry, (c)vocabulary preview that choose some difficult words, (d)bridge and connect with trigger activity, (e)meaning, and (f) spin off. In building knowledge of the student, it seems from the background activity of the student in the classroom with the teacher because some students only getting once learning poetry explored by teacher.

\section{The poetry serves a joyful learning experience while it challenges students to learn more}

Using poetry to learn vocabulary, it is a challenging for the student, while the experiences show that students joyful learning with learn more about the poetry. Although Poetry is challenging, but also make students learn more (Munden \& Skajaerstad, 2018). The deeply understanding of the students from some words that unfamiliar words before. Poetry explored meaningfully of words that can discover learning with carious to learn deeply. It is related with Hanaeur (2012) in its placed considers the need reading poetry pleasure and real-interest in correlated with joy of unravelling meaning to closes focused on form (Rosenshan \& Galloway, 2019).

\section{CONCLUSION}

The findings of this study discovered from four SMAN 1 Cikarang Selatan students as a respondent that give their experiences in using poetry to learn vocabulary. Based on the findings and discussion of the research in chapter IV, it could be concluded that (1) students' experiences in poetry assisted vocabulary learning could made the students lead to explore poetry in term of vocabulary enthusiastically, (2) poetry could as friendly use media in learning vocabulary and (3) poetry serves a joyful learning experience while it 
3034 The Students' Senior High School Experiences in Poetry Reading Activities Assisted Vocabulary Learning: Narrative Inquiry - Siti Rohmah, Muhammad Reza Pahlevi,, Abdul Kodir Al-Baekani

DOI: https://doi.org/10.31004/edukatif.v3i5.1017

challenges students to learn more. It is suitable with the aims of this research that find students' experiences in poetry-assisted vocabulary learning.

\section{REFERENCES}

Alabi, A. M. (N.D.). Teaching Vocabulary Through Poetry In An Efl Classroom. In International Journal Of New Trends In Arts, Sports \&Science Education-2015 (Vol. 4, Issue 4). Www.Ijtase.Net

Alqahtani, M. (2015). The Impotance Of Vocabulary In Language Learning And How To Be Taught. International Journal Of Teaching And Education, 21-34.

Aydinoğlu, N. (2013). Sayı 14a, Yll 2013, S.274-284 Mediterranean Journal Of Educational Research, Issue $14 a$.

Brabham, E G; Villaume, S. K. (2002). Vocabulary Instruction: Concern And Vision. The Reading Teacher, 264.

Chaton, B. (1993). Using Poetry Across The Curriculum. Phoenix, 28.

Cui, L., Hubbard, G., \& Gleeson, M. (2015). Teaching Poetry To Chinese English Majors: A Review Of Articles From 2000-2013. English Teaching: Practice \& Critique, 14(3), 270-284. Https://Doi.Org/10.1108/Etpc-03-2015-0024

Ebrahimi, S., \& Zainal, Z. (2018). Actual Poetry Reading Strategies By English As A Foreign Language Students. International Journal Of Advanced Research, 6(6), 953-975. Https://Doi.Org/10.21474/IJAR01/7299

Hanaeur, D. (1997). Poetry Reading In The Second Language Classroom. Language Awareness, 11-23.

Healy, D., \& Smyth, S. (2017). Poetry As An Engagement Strategy: A Novice Teacher Experience Of Its Use Within Lectures. Nurse Education In Practice, 24, 43-48. Https://Doi.Org/10.1016/J.Nepr.2017.03.007

Hess, N. (N.D.). Real Language Through Poetry: A Formula For Meaning Making.

Jocson, K. M. (2006). "There's A Better Word": Urban Youth Rewriting Their Social Worlds Through Poetry. Journal Of Adolescent \& Adult Literacy, 49(8), 700-707. Https://Doi.Org/10.1598/Jaal.49.8.6

Khatib, M., \& Rahimi, A. H. (2012). Literature And Language Teaching. In Journal Of Academic And Applied Studies (Vol. 2, Issue 6). Www.Academians.Org

Macdonald, K. (2018). P227 Using Poetry To Teach Students And Others About CF. Journal Of Cystic Fibrosis, 17, S123-S124. Https://Doi.Org/10.1016/S1569-1993(18)30522-8

Murray, G. (2009). Qualitative Research In Applied Lingusitics.

Özen, B., \& Behbood Mohammadzadeh, A. (N.D.). Teaching Vocabulary Through Poetry In An Efl Classroom. In International Online Journal Of Primary Education-2012 (Vol. 1, Issue 1).

Puji Widodo, H., Bagus Budi, A., Wijayanti, F., \& Negeri Jember, P. (2016). Poetry Writing 2.0: Learning To Write Creatively In A Blended Language Learning Environment. In Electronic Journal Of Foreign Language Teaching (Vol. 13, Issue 1). Http://E-Flt.Nus.Edu.Sg/

Rosenhan, C., \& Galloway, N. (2019). Creativity, Self-Reflection And Subversion: Poetry Writing For Global Englishes Awareness Raising. System, 84, 1-13. Https://Doi.Org/10.1016/J.System.2019.04.005

Saefullah, H. (2019). Introduction To Literature.

Sholikhah, A. (1970). Statistik Deskriptif Dalam Penelitian Kualitatif. Komunika: Jurnal Dakwah Dan Komunikasi, 10(2), 342-362. Https://Doi.Org/10.24090/Komunika.V10i2.953 